\section{Revista al servicio de la comunidad científica}

\author{
Journal to scientific community \\ service
}

Manuel Antonio Mattos-Vela ${ }^{1, a, b}$, Luis Cuadrao Zavaleta ${ }^{1, a, c}$

${ }^{1}$ Facultad de Odontología. Universidad Nacional Mayor de San Marcos. Lima, Perú.

${ }^{a}$ Doctor en Estomatología

${ }^{\mathrm{b}}$ Editor general de la revista Odontología Sanmarquina

c Director de la revista Odontología Sanmarquina

Correspondencia:

Manuel Antonio Mattos-Vela

Correo electrónico: mmattosv@unmsm.edu.pe

Facultad de Odontología, UNMSM. Calle Germán Amézaga 375. Lima 1, Perú.

\section{Coautor:}

Luis Cuadrao Zavaleta

Icuadraoz@unmsm.edu.pe

Fecha de recepción: 08/11/17

Fecha de aceptación: 14/11/17
En el editorial anterior, escribimos sobre la visión que tenemos como revista ${ }^{1}$. En esta ocasión nos gustaría compartir la filosofía de trabajo que deseamos nos distinga, la cual podemos resumirla en una sola palabra: servicio.

La revista Odontología Sanmarquina desea estar al servicio de la comunidad científica odontológica. Atender bien a los lectores, autores y revisores de nuestra revista, de tal manera que sea una experiencia grata acercarse a una publicación científica. Que para los lectores sea un disfrute la lectura y estudio de un artículo por su contenido intelectual, por su rigor científico, por su aporte a la profesión, por su claridad y por la presentación de sus resultados e imágenes. Que para los autores la publicación de un artículo no sea estresante, ni agotador el tiempo de espera de todo el proceso editorial; muchas veces esperando de 6 a 10 meses para saber si su manuscrito ha sido aprobado. Y si ese fuese el caso, esperar un tiempo similar hasta verlo publicado, sino mas bien, sea un proceso ágil, con tiempos razonablemente cortos de revisión y respuesta para las distintas etapas del proceso, de tal manera que si su artículo es aprobado lo vean prontamente publicado y al alcance de toda la comunidad odontológica. Si realizan una consulta sobre el estado del mismo reciban una respuesta inmediata. Que los revisores se sientan satisfechos de haber contribuido a mejorar la calidad de las publicaciones científicas, recibiendo indicaciones claras y un formato sencillo que los guie y permita plasmar sus comentarios y calificativo. Además de recibir el reconocimiento por su labor voluntaria.

Sí, deseamos servir a nuestros lectores, autores y revisores de la mejor manera. Creemos que trae más dicha dar que recibir. Queremos ser buenos servidores, y que la revista sea el medio para brindar este servicio a nuestro prójimo.

Este ideal de servicio no siempre es sencillo desarrollarlo, ya que muchas veces hay sobrecarga laboral, cansancio, necesidades personales y presiones cotidianas que impiden o distraen su aplicación. El Comité editor está integrado por docentes universitarios que no solo se dedican a la revista sino que también tienen responsabilidades académicas; sin embargo, nos esforzaremos por mantener este desafío.

¿Cómo pensamos brindar este servicio? Pues seguimos trabajando e implementando cambios, estos son:

A partir del 2018 la revista publicará cuatro números por ańo (marzo, junio, setiembre y diciembre), así, los artículos aprobados saldrán prontamente a la luz.

Estamos aumentando el número de secciones de la revista: cartas al editor, reseñas históricas y notas científicas, cuyas características están definidas en las directrices para los autores. Están invitados a enviarnos sus aportes en este mayor abanico de secciones. 
Se están acortando aún más los periodos de duración de cada etapa del proceso editorial: primera revisión de parte del comité editor, la revisión por pares externos, la decisión editorial sobre la aprobación del manuscrito, la corrección de estilo y diagramación y la revisión de la traducción del título y resumen. Esto permitirá que desde la recepción del manuscrito hasta su aprobación final pase en promedio un mes y medio. Para esto se requiere también la colaboración de los autores, respondiendo en los plazos señalados por la revista aquello que se solicite. Contamos con un flujograma que puede ser revisado en la página web de la revista, en el cual se resume la duración de cada una de estas etapas.

Se han realizado algunas modificaciones en las políticas de la revista y las directrices para los autores, brindando una mayor orientación para mejorar la calidad del contenido y comunicación de los artículos que se presenten. Por ejemplo, se han desarrollado más los aspectos éticos que se deben considerar en las investigaciones y aspectos de redacción para la presentación de los manuscritos.
Finalmente, queremos agradecer mucho el trabajo de cada uno de los revisores que han colaborado con nosotros este año, todos son investigadores y especialistas en un campo de la Odontología, externos a nuestra institución, la gran mayoría de otros países y de manera voluntaria han brindado su servicio. Con la revisión cuidadosa contribuyen a mejorar la calidad de los manuscritos y la decisión editorial para la publicación del artículo. En este número de la revista queremos reconocer públicamente la labor de cada uno de ellos incluyendo una lista con sus nombres.

\section{Referencias bibliográficas}

1. Mattos-Vela MA, Cuadrao Zavaleta L. Seguimos avanzando [editorial]. Odontol Sanmarquina. 2017; 20(1):3-4. 